\title{
Socio-demographic factors related to under-diagnosis of childhood asthma in Upper Silesia, Poland
}

\author{
Jan E. Zejda', Małgorzata Farnik², Irena Smółka', Joshua Lawson³, Grzegorz M. Brożek' \\ ${ }^{1}$ Department of Epidemiology, School of Medicine in Katowice, Medical University of Silesia, Poland \\ 2 Department of Pneumonology, School of Medicine in Katowice, Medical University of Silesia, Poland \\ ${ }^{3}$ Canadian Centre for Health and Safety in Agriculture, University of Saskatchewan, Saskatoon, Canada
}

Zejda J E, Farnik M, Smółka I, Lawson J, Brożek G M. Socio-demographic factors related to under-diagnosis of childhood asthma in Upper Silesia, Poland. Ann Agric Environ Med. 2017; 24(2): 171-175. https://doi.org/10.26444/aaem/74532

\begin{abstract}
Introduction. The presented study of 4,535 children aged 7-17 years in the Upper Silesian region of Poland yielded 186 cases of previously known asthma, and 44 children with newly diagnosed asthma. The aim of the presented study was to identify non-medical factors that could explain why children with a newly established diagnosis ('undiagnosed asthma') had not been diagnosed in the past.

Materials and method. The study was performed according to a case-control design. Parents of the children answered questionnaires on socio-economic status and family-related factors. Statistical determinants of undiagnosed asthma were explored using raw (OR) and logistic odds ratios with their 95\% confidence intervals (logOR, 95\%Cl).

Results. Children with undiagnosed asthma were younger compared to the group with previously known asthma (11.3 \pm 2.1 vs. $12.6 \pm 2.5$ years; $p=0.0008$ ). Newly diagnosed cases were more frequent in children who had less parental attention (less than 1 hour/day spent by parent with child - OR=4.36; 95\%Cl: 1.76-10.81) and who were not registered with specialized health care $(\mathrm{OR}=2.20 ; 95 \% \mathrm{Cl}$ : $0.95-5.06)$. Results of logistic regression analysis suggest that under-diagnosis of asthma is related to age below 12 years - logOR $=3.59(95 \% \mathrm{Cl}: 1.28-10.36)$, distance to a health centre $>5 \mathrm{~km}-\operatorname{logOR}=3.45(95 \% \mathrm{Cl}$ : 1.05-11.36), time spent with child $<1$ hour/day - logOR $=6.28$ (95\%Cl: 1.98-19.91).

Conclusion. Among non-medical determinants of undiagnosed asthma the age of a child plays a major role. Another factors of importance is the large distance between residence and health centre, and low parental attention at home.
\end{abstract}

Key words

childhood asthma, under-diagnosis, socio-economic factors

\section{INTRODUCTION}

Globally, asthma is a large problem among children. Despite this, geographic variation in asthma prevalence has been reported. Results from population-based surveys on childhood asthma in Poland performed within the ISAAC programme showed a relatively low prevalence of the disease, ranging between $5.8 \%-6.8 \%$ [1]. However, it is suspected that these figures may reflect under-diagnosis or under-reporting of the disease. Results of clinical verification projects in Poland suggest that the magnitude of under-diagnosis could be as large as 50\% $[2,3]$. Cross-sectional studies in 1993, 2002 and 2007 by the authors of the presented study in children of Upper Silesia, Poland, showed an increase in the prevalence of childhood asthma, from $3.4 \%-8.5 \%$ during that period [4], which suggests that the burden of disease and subsequent costs could be increasing as the prevalence of asthma moves closer to that experienced in westernized countries. A part of the explanation of geographic variation in asthma prevalence could therefore be due to diagnosing or reporting patterns. Given the questionnaire-derived morbidity rates, it is rather unlikely that the estimates for Poland are subject to the so-

\footnotetext{
Address for correspondence: Jan E. Zejda, Department of Epidemiology, Medical University of Silesia, Medykow 18, 40-752 Katowice, Poland

Tel./fax: +4832 2523734

E-mail: jzejda@sum.edu.pl

Received: 20 June 2013; accepted: 9 May 2014; first published on January 2017
}

called over-diagnosis of childhood asthma, the phenomenon described in some westernized regions $[5,6]$.

This study of children yielded 186 cases $(4.1 \%)$ of previously known diagnosis of asthma, established by physicians [7]. Because of the low prevalence of childhood asthma, a follow-up study was designed to explore issues around diagnosing patterns. The objectives were to examine a subgroup of children from the original study with respiratory symptoms and no diagnosis of asthma to identify children with 'undiagnosed asthma', as well as to identify host, socioeconomic and family-related factors that determine the likelihood of children not receiving an asthma diagnosis prior to the original study when asthma was present. This would expand on the previous research by identifying potential reasons for the under-diagnosis of childhood asthma in Poland in an attempt to reduce its prevalence and improve subsequent care.

\section{MATERIALS AND METHOD}

A respiratory health survey using questions from the ISAAC questionnaire was performed in $2010 \mathrm{in}$ and around the city of Katowice in the Silesian region of Poland. The study included 4,535 urban and rural children aged 7-17 years (participation rate $=68 \%$ ). Children with a previously established diagnosis of asthma were classified as 'Previously Known Asthma', while children who did not have a previous diagnosis but 
who reported current asthma-like symptoms were classified as 'Suspected Asthma'. Children were classified as having suspected asthma if their parents reported one of the following in the past 12 months: chest wheezing outside of respiratory infection, attacks of dyspnea outside of respiratory infection, attacks of dyspnea on or after physical exercise or exposure to cold air, or dry cough at night, apart from a cough associated with a cold or chest infection.

Children with suspected asthma were referred to a pulmonologist to determine the presence or absence of asthma. The evaluating physician interviewed both children and their parents, reviewed existing medical records, and had access to spirometry and skin-prick tests. The diagnosis of asthma was based on international GINA guidelines [8]. Spirometry was performed using an EasyOne spirometer and followed ATS/ERS guidelines [9]. Interpretation of lung function was based on percent predicted values [10,11]. Lung function was considered normal if FEV, $\mathrm{FVC}$ and $\mathrm{PEF}$ values were at least $80 \%$ of predicted values, and the $\mathrm{FEV}_{1} / \mathrm{FVC}$ ratio was greater than $75 \%$. Bronchial hyperresponsiveness was examined using an exercise challenge test [12]. The procedure of the sub-maximal exercise test involved stepping up and down on a single step with metronome rhythm. Spirometry was measured before the step-test and at 0,5 and 15 minutes after exercise. Hyperresponsiveness was considered present if there was a $\mathrm{FEV}_{1}$ decrease of greater than $15 \%$. Skin prick tests (Allergopharma, Germany) were performed according to the recommendations by the Polish Allergological Association. Children in the suspected asthma group who received a diagnosis of asthma from the study physician were classified as 'Newly Diagnosed Asthma'.

Data analysis was based on comparisons between the "Previously Known Asthma" and "Newly Diagnosed Asthma' groups. The groups were compared in terms of demographic, socio-economic and family life-related characteristics, according to parental responses to the ISAAC questionnaire. A separate questionnaire included questions addressing specific socio-demographic issues (parental opinions regarding child's health and quality of health care, registration of a child with a specialized health centre, residence on a farm, economic status of the family, distance to the health centre, average time spent by mother in direct and active contact with child at home).

All statistical analyses were performed using procedures available in the SAS statistical package [SAS Institute Inc., Cary, NC, USA]. Statistical significance of comparisons between continuous variables was assessed using independent samples t-tests and of categorical variables by means of the chi-square test. Associations between the examined factors and the under-diagnosis of asthma were analyzed using logistic regression. The strengths of associations were expressed by odds ratios and their $95 \%$ confidence intervals (OR, 95\%CI). Variables were selected to the final model using 'backward' selection procedures, and included all variables for which the crude odds ratio obtained in simple analyses was 1.5 or above, in addition to variables known to be confounders from the scientific literature. Statistical significance was based on the criterion: $\mathrm{p}<0.05$.

\section{RESULTS}

The study yielded 186 cases (4.1\%) of previously reported asthma. The complete questionnaire-derived data were available in 184 children in this group. In addition to 'Previously Known Asthma', 167 children from the 'Suspected Asthma Group' had current asthma-like symptoms. After clinical examination of all 167 subjects, 44 children of the 'Suspected Asthma Group' were diagnosed for asthma ('Newly Diagnosed Asthma'). Thus, the estimated level of under-diagnosis of the disease was 19\% (44 out of 184+44).

Age and BMI were originally considered as continuous measures. Children in the group 'Previously Known Asthma' $(\mathrm{n}=184)$ were older than the 44 children in the group 'Newly Diagnosed Asthma' (12.6 \pm 2.5 years and 11.3 \pm 2.1 years, respectively; $\mathrm{p}=0,0008)$, but the groups did not differ in terms of the body mass index $\left(18.0 \pm 3.6 \mathrm{~kg} / \mathrm{m}^{2}\right.$ and $17.2 \pm 2.8 \mathrm{~kg} / \mathrm{m}^{2}$, respectively; $\mathrm{p}=0.2$ ).

Results of simple analyses involving potential sociodemographic determinants of under-diagnosis of asthma showed that the newly diagnosed cases were more likely to be younger (Tab. 1). There was also a trend towards more newly diagnosed asthma among those with a higher maternal education level (Tab. 1).

Table 1. Socio-demographic determinants of undiagnosed asthma (newly diagnosed asthma)

\begin{tabular}{|c|c|c|c|c|}
\hline Variable & Value & $\begin{array}{c}\text { Newly Diagnosed } \\
\text { Asthma } \\
\mathrm{n}(\%)\end{array}$ & $\begin{array}{l}\text { Odds Ratio* } \\
\qquad(95 \% \mathrm{Cl})\end{array}$ & $\mathrm{p}^{\prime * *}$ \\
\hline \multirow{2}{*}{ Age } & Below 12 years & $26(26.8 \%)$ & \multirow{2}{*}{$\begin{array}{c}2.25 \\
(1.15-4.41)\end{array}$} & \multirow{2}{*}{0.01} \\
\hline & 12 years or above & $18(13.9 \%)$ & & \\
\hline \multirow{2}{*}{ Gender } & Girls & $22(24.1 \%)$ & \multirow{2}{*}{$\begin{array}{c}1.65 \\
(0.85-3.20)\end{array}$} & \multirow{2}{*}{0.1} \\
\hline & Boys & $22(16.1 \%)$ & & \\
\hline \multirow{2}{*}{$\begin{array}{l}\text { Place } \\
\text { of residence }\end{array}$} & Urban & $29(22.6 \%)$ & \multirow{2}{*}{$\begin{array}{c}1.64 \\
(0.82-3.26)\end{array}$} & \multirow{2}{*}{0.1} \\
\hline & Rural & $15(15.1 \%)$ & & \\
\hline \multirow{2}{*}{$\begin{array}{l}\text { Education } \\
\text { of mother }\end{array}$} & Below high school & $14(14.2 \%)$ & \multirow{2}{*}{$\begin{array}{c}1.85 \\
(0.92-3.70)\end{array}$} & \multirow{2}{*}{0.08} \\
\hline & High school or above & $30(23.6 \%)$ & & \\
\hline \multirow{2}{*}{$\begin{array}{l}\text { Education } \\
\text { of father }\end{array}$} & Below high school & $24(18.4 \%)$ & \multirow{2}{*}{$\begin{array}{c}1.33 \\
(0.68-2.61)\end{array}$} & \multirow{2}{*}{0.3} \\
\hline & High school or above & $20(23.2 \%)$ & & \\
\hline \multirow{2}{*}{$\begin{array}{l}\text { Employment } \\
\text { of mother }\end{array}$} & Unemployed & $13(19.1 \%)$ & \multirow{2}{*}{$\begin{array}{c}1.02 \\
(0.50-1.98\end{array}$} & \multirow{2}{*}{0.8} \\
\hline & Employed & $31(20.3 \%)$ & & \\
\hline \multirow{2}{*}{$\begin{array}{l}\text { Employment } \\
\text { of father }\end{array}$} & Unemployed & $6(27.2 \%)$ & \multirow{2}{*}{$\begin{array}{c}1.50 \\
(0.55-4.09)\end{array}$} & \multirow{2}{*}{0.4} \\
\hline & Employed & $38(20.0 \%)$ & & \\
\hline
\end{tabular}

* - for each variable the reference category of OR is the variable's value associated with lower frequency of newly-diagnosed asthma (\%)

** - p value provided by chi-square test

With regard to parental history of respiratory or allergic disease, none of the associations were statistically significant, although there was a trend towards more newly diagnosed asthma among children without a maternal history of chronic bronchitis (Tab. 2).

When considering the combined variables of family history, the results were consistent. Under-diagnosis was poorly associated with parental asthma (asthma in mother or father): $\mathrm{OR}=1.62(95 \% \mathrm{CI}: 0.62-4.21 ; \mathrm{p}=0.3)$. Parental allergic diseases (hay fever or eczema or allergy) also did not relate to under-diagnosis: in the mother $\mathrm{OR}=1.16$ (95\% CI: 0.56-2.39; $\mathrm{p}=0.6$ ); in the father $\mathrm{OR}=1.38$ (95\%CI: 0.65-2.91; $\mathrm{p}=0.3)$. Respiratory/allergic health status of siblings did not 
Table 2. Parental history of respiratory/allergic diseases as determinants of undiagnosed asthma (newly diagnosed asthma)

\begin{tabular}{|c|c|c|c|c|}
\hline Variable & Value & $\begin{array}{c}\text { Newly Diagnosed Asthma } \\
\text { N (\%) }\end{array}$ & $\begin{array}{l}\text { Odds Ratio* } \\
(95 \% \mathrm{Cl})\end{array}$ & $\mathrm{p}^{\prime * *}$ \\
\hline \multirow{2}{*}{ Asthma in mother } & No & $36(19.5 \%)$ & \multirow{2}{*}{$\begin{array}{c}1.52 \\
(0.45-5.06)\end{array}$} & \multirow{2}{*}{0.4} \\
\hline & Yes & $4(26.6 \%)$ & & \\
\hline \multirow{2}{*}{$\begin{array}{l}\text { Chronic bronchitis in } \\
\text { mother }\end{array}$} & No & $35(20.5 \%)$ & \multirow{2}{*}{$\begin{array}{c}3.50 \\
(0.79-15.43)\end{array}$} & \multirow{2}{*}{0.07} \\
\hline & Yes & $2(6.9 \%)$ & & \\
\hline \multirow{2}{*}{ Hay fever in mother } & No & $30(19.7 \%)$ & \multirow{2}{*}{$\begin{array}{c}1.26 \\
(0.53-2.96)\end{array}$} & \multirow{2}{*}{0.5} \\
\hline & Yes & $8(16.3 \%)$ & & \\
\hline \multirow{2}{*}{$\begin{array}{l}\text { Atopic eczema in } \\
\text { mother }\end{array}$} & No & $35(20.1 \%)$ & \multirow{2}{*}{$\begin{array}{c}1.93 \\
(0.54-6.72)\end{array}$} & \multirow{2}{*}{0.2} \\
\hline & Yes & $3(11.5 \%)$ & & \\
\hline \multirow{2}{*}{ Allergy in mother } & No & $28(18.3 \%)$ & \multirow{2}{*}{$\begin{array}{c}1.11 \\
(0.49-2.49)\end{array}$} & \multirow{2}{*}{0.7} \\
\hline & Yes & $10(20.0 \%)$ & & \\
\hline \multirow{2}{*}{$\begin{array}{l}\text { Asthma } \\
\text { in father }\end{array}$} & No & $35(19.0 \%)$ & \multirow{2}{*}{$\begin{array}{c}2.12 \\
(0.60-7.46)\end{array}$} & \multirow{2}{*}{0.2} \\
\hline & Yes & $4(33.3 \%)$ & & \\
\hline \multirow{2}{*}{$\begin{array}{l}\text { Chronic bronchitis in } \\
\text { father }\end{array}$} & No & $35(20.3 \%)$ & \multirow{2}{*}{$\begin{array}{c}2.29 \\
(0.50-10.38)\end{array}$} & \multirow{2}{*}{0.2} \\
\hline & Yes & $2(10.0 \%)$ & & \\
\hline \multirow{2}{*}{ Hay fever in father } & No & $33(20.3 \%)$ & \multirow{2}{*}{$\begin{array}{c}1.20 \\
(0.48-2.96)\end{array}$} & \multirow{2}{*}{0.6} \\
\hline & Yes & $7(17.5 \%)$ & & \\
\hline \multirow{2}{*}{ Atopic eczema in father } & No & $35(19.3 \%)$ & \multirow{2}{*}{$\begin{array}{c}1.07 \\
(0.22-5.21)\end{array}$} & \multirow{2}{*}{0.9} \\
\hline & Yes & $2(18.1 \%)$ & & \\
\hline \multirow{2}{*}{$\begin{array}{l}\text { Allergy } \\
\text { in father }\end{array}$} & No & $31(18.3 \%)$ & \multirow{2}{*}{$\begin{array}{c}1.27 \\
(0.47-3.41)\end{array}$} & \multirow{2}{*}{0.6} \\
\hline & Yes & $6(22.2 \%)$ & & \\
\hline
\end{tabular}

* - for each variable the reference category of OR is the variable's value associated with lower frequency of newly diagnosed asthma (\%)

** - $p$ value provided by chi-square test

explain the occurrence of undiagnosed asthma: no diagnosis of chronic bronchitis - OR=1.02 (95\%CI: 0.38-2.75), no diagnosis of hay fever $-\mathrm{OR}=1.28$ (95\%CI: $0.51-3.20)$, no diagnosis of atopic eczema - OR=1.32 (95\%CI: 0.46-3.75), and no diagnosis of any allergy - OR=2.50 (95\%CI: 0.82-7.62).

Table 3 shows the associations between 'Newly Diagnosed Asthma' and other respiratory and allergic diseases in the participating children, diagnosed by a physician in the past.

Table 3. Undiagnosed asthma (newly-diagnosed asthma) according to health status of children in the study

\begin{tabular}{|c|c|c|c|c|}
\hline Variable & Value & $\begin{array}{c}\text { Newly Diagnosed } \\
\text { Asthma } \\
\mathrm{n}(\%)\end{array}$ & $\begin{array}{l}\text { Odds Ratio* } \\
\text { (95\%Cl) }\end{array}$ & $' p^{\prime * *}$ \\
\hline \multirow{2}{*}{$\begin{array}{l}\text { Child's health } \\
\text { (parental opinion) }\end{array}$} & Good/Very good & $29(19.3 \%)$ & \multirow{2}{*}{$\begin{array}{c}1.05 \\
(0.50-2.17)\end{array}$} & \multirow{2}{*}{0.8} \\
\hline & Moderate/Poor & $13(18.5 \%)$ & & \\
\hline \multirow{2}{*}{$\begin{array}{l}\text { Pneumonia in the } \\
\text { past }^{* * *}\end{array}$} & No & $26(22.6 \%)$ & \multirow{2}{*}{$\begin{array}{c}1.28 \\
(0.60-2.69)\end{array}$} & \multirow{2}{*}{0.5} \\
\hline & Yes & $13(18.5 \%)$ & & \\
\hline \multirow{2}{*}{$\begin{array}{l}\text { Spastic bronchitis } \\
\text { in the past }\end{array}$} & No & $36(27.4 \%)$ & \multirow{2}{*}{$\begin{array}{c}5.49 \\
(1.85-16.23)\end{array}$} & \multirow{2}{*}{0,0008} \\
\hline & Yes & $4(6.4 \%)$ & & \\
\hline \multirow{2}{*}{$\begin{array}{l}\text { Hay fever } \\
\text { in the past*** }\end{array}$} & No & $19(25.0 \%)$ & \multirow{2}{*}{$\begin{array}{c}1.79 \\
(0.89-3.60)\end{array}$} & \multirow{2}{*}{0.09} \\
\hline & Yes & $21(15.6 \%)$ & & \\
\hline \multirow{2}{*}{$\begin{array}{l}\text { Atopic eczema } \\
\text { in the past }\end{array}$} & No & $28(21.0 \%)$ & \multirow{2}{*}{$\begin{array}{c}1.02 \\
(0.47-2.18)\end{array}$} & \multirow{2}{*}{0.9} \\
\hline & Yes & $12(20.6 \%)$ & & \\
\hline \multirow{2}{*}{$\begin{array}{l}\text { Allergy } \\
\text { in the past *** }\end{array}$} & No & $18(21.9 \%)$ & \multirow{2}{*}{$\begin{array}{c}1.11 \\
(0.55-2.22)\end{array}$} & \multirow{2}{*}{0.7} \\
\hline & Yes & $23(20.1 \%)$ & & \\
\hline
\end{tabular}

* - for each variable the reference category of $O R$ is the variable's value associated with lower frequency of newly diagnosed asthma (\%)

** - $p$ value provided by chi-square test

*** - disease diagnosed by physician before the study was implemented
Table 4. Socio-economic determinants of undiagnosed asthma (newlydiagnosed asthma)

\begin{tabular}{|c|c|c|c|c|}
\hline Variable & Value & $\begin{array}{c}\text { Newly Diagnosed } \\
\text { Asthma } \\
\mathrm{n}(\%)\end{array}$ & $\begin{array}{l}\text { Odds Ratio* } \\
(95 \% \mathrm{Cl})\end{array}$ & $\mathrm{p}^{\prime * *}$ \\
\hline \multirow{2}{*}{$\begin{array}{l}\text { Family } \\
\text { completeness }\end{array}$} & Father + mother & $41(42.2 \%)$ & \multirow{2}{*}{$\begin{array}{c}1.46 \\
(0.34-6.20)\end{array}$} & \multirow{2}{*}{0.6} \\
\hline & Father or mother & $3 / 9(33.3 \%)$ & & \\
\hline \multirow{2}{*}{$\begin{array}{l}\text { Opinion } \\
\text { regarding } \\
\text { health care }\end{array}$} & Good quality & $33(40.7 \%)$ & \multirow{2}{*}{$\begin{array}{c}1.03 \\
(0.41-2.57)\end{array}$} & \multirow[b]{2}{*}{0.9} \\
\hline & Other & $10(40.0 \%)$ & & \\
\hline \multirow{2}{*}{$\begin{array}{l}\text { Child registered } \\
\text { with specialized } \\
\text { health care }\end{array}$} & No & $18(51.4 \%$ & \multirow{2}{*}{$\begin{array}{c}2.20 \\
(0.95-5.06)\end{array}$} & \multirow[b]{2}{*}{0.05} \\
\hline & Yes & $23(32.3 \%)$ & & \\
\hline \multirow{2}{*}{$\begin{array}{l}\text { Distance from } \\
\text { home to health } \\
\text { care centre }\end{array}$} & Less than $5 \mathrm{~km}$ & $30(37.0 \%)$ & \multirow{2}{*}{$\begin{array}{c}1.83 \\
(0.75-4.41)\end{array}$} & \multirow{2}{*}{0.1} \\
\hline & $5 \mathrm{~km}$ or more & $14(51.8 \%)$ & & \\
\hline \multirow{2}{*}{$\begin{array}{l}\text { Economic status } \\
\text { (self-assesment) }\end{array}$} & Good & $36(42.3 \%)$ & \multirow{2}{*}{$\begin{array}{c}1.95 \\
(0.69-5.49)\end{array}$} & \multirow{2}{*}{0.1} \\
\hline & Poor & $6(27.2 \%)$ & & \\
\hline \multirow{2}{*}{$\begin{array}{l}\text { Average time } \\
\text { spent with a } \\
\text { child }\end{array}$} & Less than 1 hour/day & $36(52.1 \%)$ & \multirow{2}{*}{$\begin{array}{c}4.36 \\
(1.76-10.81)\end{array}$} & \multirow[b]{2}{*}{0.01} \\
\hline & More than 1 hour/day & $8(20.0 \%)$ & & \\
\hline \multirow{2}{*}{ No. of siblings } & $0-2$ & $33(19.8 \%)$ & \multirow{2}{*}{$\begin{array}{c}1.19 \\
(0.42-3.35)\end{array}$} & \multirow{2}{*}{0.7} \\
\hline & 3 or more & $5(17.2 \%)$ & & \\
\hline \multirow{2}{*}{$\begin{array}{l}\text { Residence on } \\
\text { the farm }\end{array}$} & No & $38(20.5 \%)$ & \multirow{2}{*}{$\begin{array}{c}2.58 \\
(0.74-8.92)\end{array}$} & \multirow{2}{*}{0.1} \\
\hline & Yes & $3(9.0 \%)$ & & \\
\hline
\end{tabular}

* - for each variable the reference category of $O R$ is the variable's value associated with lower frequency of newly diagnosed asthma (\%)

** - p value provided by chi-square test

New cases of asthma were found more frequently in children without previous diagnosis of spastic bronchitis. None of the other variables showed statistically significant associations with newly diagnosed asthma. When any allergic disease in a child (composed variable: hay fever or eczema or allergy) was used, its effect did not reach statistical significance: $\mathrm{OR}=1.32$ (95\%CI: $0.60-2.88 ; \mathrm{p}=0.4$ ).

108 parents of children ('Newly Diagnosed Asthma' ( $\mathrm{n}=44)$; 'Previously Known Asthma' ( $n=64)$ agreed to participate in an additional questionnaire survey focusing on specific family issues, including socio-economic status. The results of simple analyses are shown in Table 4 . New cases of asthma were more frequent among children who had less parental attention (less than 1 hour/day spent by parent with the child) and who were not registered with specialized health care.

Results of simple analyses were verified by logistic regression analysis. The model included all variables for which odds ratio obtained in simple analyses was 1.5 or above. However, past physician-made diagnoses of respiratory or allergic diseases in a child were not used in multivariable analysis. Moreover, residence on the farm and no rural residence was entered in the model. The following independent variables were used ('p' values of coefficients of regression are shown in the brackets): age $(p=0.01)$, gender $(p=0.8)$, residence on the farm $(p=0.1)$, education of mother $(p=0.4)$, asthma in mother $(\mathrm{p}=0.9)$, chronic bronchitis in mother $(\mathrm{p}=0.1)$, atopic eczema in mother $(\mathrm{p}=0.6)$, asthma in father $(\mathrm{p}=0.1)$, chronic bronchitis in father $(p=0.1)$, allergy in siblings $(p=0.3)$, dampness in house $(\mathrm{p}=0.4)$, specialized health care $(\mathrm{p}=0.6)$ distance to health care centre $(\mathrm{p}=0.09)$, economic status $(\mathrm{p}=0.5)$, and time spent with child $(\mathrm{p}=0,003)$.

In multivariate analysis the following variables appeared to be related to under-diagnosed asthma: age below 12 
years $-\mathrm{OR}=3.59(1.28-10.36)$, distance to health centre $>5 \mathrm{~km}-\mathrm{OR}=3.45$ (95\%CI: 1.05-11.36), time spent with child $<1$ hour/day - OR $=6.28$ (95\%CI: $1.98-19.91)$. The results were unlikely to be affected by multi-collinearity since 2 independent variables, namely age of a child and time spent with a child, were not statistically significantly associated $(\mathrm{p}=0.7)$.

\section{DISCUSSION}

Under-diagnosis of childhood asthma and subsequent inadequate control of the disease is an important clinical and public health issue $[13,14]$. The presented findings suggest that in the study area the level of under-diagnosis of the disease approaches $20 \%$. These problems have clinical and public health implications. Current diagnostic guidelines are often not applied [15]. Moreover, children with less respiratory symptoms, with less severe presentation or without the usual allergic co-morbidities, are more likely to be undiagnosed $[16,17]$. The presented findings also suggest that socio-demographic and other family-related factors play a role in the under-diagnosis of childhood asthma. Among the non-medical correlates of under-diagnosis, the age of a child plays a major role. Other characteristics of importance that increase the likelihood of under-diagnosis include a large distance between a child's residence and health care centre, as well as low parental attention.

It is well-known that age plays a big role in the natural history of asthma. Increases in symptoms and a more apparent asthmatic specificity with age is also well-known. Allergic presentation and seasonality of the symptoms become more evident and the severity of the disease is more visible in school children, compared with younger age groups. As a result, diagnosis of asthma is usually possible through longterm follow up and a careful time-consuming differential diagnosis [13]. This phenomenon is also described regarding adult asthma - the diagnosis of asthma is often overlooked in patients with a mild form of the disease [18].

Another important factor channeled by the context of age is the use of lung function assessment in the diagnosis of asthma. The presented study shows that only one-third of asthmatic children had had spirometric assessment in the past year [7]. The problem of a lack of spirometric testing is universal. It is clearly an underused procedure both in a primary and in secondary care settings and goes beyond Poland [5]. The impact of age when arriving at a final diagnosis is also essential within the context of family-related factors. Accumulation of symptoms and their persistence over time, together with increasing intensity, as well as their impact on developing social activities of the affected child, are more visible in older children and all are more likely to motivate parents seek advice from physicians.

A number of socio-economic and other family related factors could be discussed in terms of under-diagnosis or delayed diagnosis of existing asthma in a child. A recent study performed in metropolitan France showed the role of a low socio-economic status of families probably affecting access to health care services [19]. However, the focus of this large, earlier study was on the 'under-treatment' of asthma and its correlates. The impact of distance between residence and health care centre, as suggested by the current findings, cannot be easily interpreted. It would be too naïve to directly connect the distance with access to diagnostic facilities. However, accessibility includes many components, such as predisposing determinants (demographic and social factors, beliefs), enabling determinants (family and community factors), as well as perceived and evaluated illness-related determinants [20]. From that point of view, it cannot be excluded that the statistical effect of 'distance' is a surrogate for social and cultural influences that were not measured in the presented study, but could be essential in communities located outside urban areas.

Along this line is the finding that undiagnosed children have less attention from their parents in terms of average time the parents spend with them. The differential impact may reflect an interplay of cultural attitudes, communication, or some other aspect of physician/patient interaction [21]. The issue is more evident in multicultural societies with a mixed ethnic composition. Specificity of cultural and life-style patterns confounds between-population comparisons and above all the issue addressed in this study has no sufficient literature-based evidence. In an earlier report concerning childhood asthma in Denmark, under-diagnosis was independently related to low physical activity, high body mass, serious family problems, passive smoking and absence of rhinitis [22]. Two factors, namely family problems and smoking by family members, might be correlated and serve as a surrogate for a reduced parental focus on the child's symptoms. Such an interpretation adds to another finding - of association of under-diagnosis with the low socio-economic status of families found in Australia [23]. In adults, under-presentation of respiratory symptoms by asthmatic patients seems to be the most important cause of under-diagnosis of the disease [24]. The finding cannot be easily extrapolated to childhood asthma; however, the role of parents in recognizing and reporting symptoms cannot be neglected. Social or behavioural factors within the family unit may limit the recognition of symptoms [17]. In the UK, undiagnosed asthma, defined as significant asthmatic symptoms, increased with worsening socio-economic deprivation. The mechanisms behind an apparent exposureresponse pattern in the current study (under-diagnosis: $4.3 \%$ $7.3 \%-9.0 \%$ ) remain unknown, but factors affecting family life may influence behaviour arising from symptoms in the child's parents [25]. The role of family-related factors could be further supported by the finding concerning family history of respiratory diseases. Parents suffering from respiratory disorders are more likely to duly respond to respiratory health symptoms in their children. In this study, undiagnosed asthma was less frequent in families where the mothers or fathers had chronic bronchitis, although parental asthma did not show a similar impact. The lack of the latter effect could be explained by the small numbers of asthma cases among parents.

There are a number of limitations to the presented study. First, there was a relatively small sample size. However, the groups were derived from a large cross-sectional study which included 4,500 children. All but 2 children with previously diagnosed asthma were included in the analysis, and the search for undiagnosed asthma involved a detailed clinical assessment of 167 suspected cases. Despite the small sample size, some statistically significant results were obtained, suggesting sufficient power for some associations. In addition to this, a high participation rate was experienced, suggesting that while there is potential for Type II statistical error for 
some associations, these associations would be relatively unbiased. Another limitation stems from questionnairederived information on factors explored for potential risk factors of under-diagnosis. The true reliability of the answers remains unknown; however, many epidemiological studies depend on questionnaires. Some concern might be related to nosologic preference. Although traditional labels like 'spastic/asthmatic bronchitis' are not uncommon in Poland, undiagnosed asthma was not frequent among children who had 'spastic/asthmatic bronchitis' diagnosed in the past. Of more interest is the limitation resulting from the unknown level of asthma. It cannot be excluded that undiagnosed asthma had a less severe course than asthma previously diagnosed. Nevertheless, both clinical presentations belong to the common category of asthma, and the objective of the study was to compare groups classified by diagnosis and not by the level of the disease.

\section{CONCLUSIONS}

The low age of a child plays a major role among the nonmedical determinants of undiagnosed asthma. Another factor of importance is the large distance between place of residence and health centre. Furthermore, low parental attention seems to be an important determinant of underdiagnosis of childhood asthma.

\section{Acknowledgements}

This study was supported by research grant 'Environmental determinants of under-diagnosis of childhood asthma' (Grant No.: NN404029339), from the National Science Centre in Krakow, Poland.

\section{REFERENCES}

1. Bręborowicz A, Lis G, Cichocka-Jarosz E, Alkiewicz J, Pietrzyk J. Prevalence and severity of asthma symptoms in schoolchildren in Poland (ISAAC study). Pediatr Pol. 2005; 80(10): 866-873.

2. Kuprys-Lipinska I, Elgalal A, Kuna P. Niedodiagnozowanie i brak właściwej terapii astmy - badanie populacji ogólnej mieszkańców województwa łódzkiego (Polska) [The underdiagnosis and undertreatment of asthma in general population of the Lodz Province (Poland)]. Pneumonol Alergol Pol. 2010; 78(1): 21-27.

3. Doniec Z, Wroński M, Willim G, Pisiewicz K, Kurzawa R. Czy astma oskrzelowa u dzieci jest nadal chorobą „,niedodiagnozowaną”? [Is bronchial asthma in children still „underdiagnosed” disease?]. Acta Pneumonologica et Allergologica Pediatrica. 2001(1); 4: 56-60.

4. Brożek M, Zejda JE, Kowalska M, Gębuś M, Kępa K, Igielski M. Opposite trends of allergic disorders and respiratory symptoms in children over a period of large-scale ambient air pollution decline. Pol J Environ Stud. 2010; 19(6): 1133-1138.
5. Contoli M, Papi A. When asthma diagnosis becomes a challenge. Eur Respir J. 2010; 36(2): 231-233.

6. Luks VP, Vandemheen KL, Aaron SD. Confirmation of asthma in an era of overdiagnosis. Eur Respir J. 2010; 36(2): 255-260.

7. Zejda JE, Brożek GM, Farnik M, Smółka I. Social and family-related correlates of medical care utilization by asthmatic children in Upper Silesia, Poland. Ann Agric Environ Med. 2012; 19(1): 141-146.

8. Global strategy for asthma management and prevention - updated 2012. Global Initiative for Asthma 2012. http://www.ginasthma.org (accessed: 25 Jan 2013).

9. Brusasco V, Crapo R, Viegi G. ATS/ERS Task Force: Standardisation for lung function testing - General considerations for lung function testing. Eur Respir J. 2005; 26(1): 153-161.

10. Dockery DW, Berkey C S, Ware JH. Distribution of forced vital capacity and forced expiratory volume in one second in children 6 to 11 years of age. Am Rev Respir Dis. 1983; 128(3): 405-12.

11. Hsu KH, Jenkins DE; Hsi BP, Bourhofer E, Thompson V, Tanakawa $\mathrm{N}$ et al. Ventilatory functions of normal children and young adultsMexican-American, white, and black. I. Spirometry. J Pediatr. 1979; 95(1): 14-23.

12. Gerald LB, Grad R, Turner-Henson A, Hains C, Tang S, Feinstein R et al. Validation of a multistage asthma case-detection procedure for elementary school children. Pediatrics. 2004; 114(4): 459-468.

13. Bacharier LB, Boner A, Carlsen KH, Eigenmann PA, Frischer T, Gotz $\mathrm{M}$ et al. Diagnosis and treatment of asthma in childhood: a PRACTALL consensus report. Allergy. 2008; 63(1): 5-34.

14. Papadopoulos NG, Arakowa H, Carlsen KH, Custovic A, Gern J, Lemanske R et al. International consensus on (ICON) pediatric asthma. Allergy. 2012; 67(8): 976-997.

15. Baldacci S, Maio S, Simoni M, Cerrai S, Sarno G, Silvi P et al. The ARGA study with general practitioners: impact of medical education on asthma/rhinitis management. Respir Med. 2012; 106(6): 777-785.

16. Ruokonen M, Kaila M, Haataja R, Korppi M, Paassilta M. Allergic rhinitis in school-aged children with asthma - still under-diagnosed and undertreated? A retrospective study in a children's hospital. Pediatr Allergy Immunol. 2010; 21(1): e149-e154.

17. Gerald JK, Sun Y, Grad R, Gerald LB. Asthma morbidity among children evaluated by asthma case detection. Pediatrics. 2009; 124(5): e927-e933.

18. Nathell L, Larsson K, Jensen I. Determinants of underdiagnosed asthma. Allergy. 2002; 57(8): 687-693.

19. Annesi-Maesano I, Sterlin C, Caillaud D, de Blay F, Lavaud F, Charpin $\mathrm{D}$ et al. Factors related to under-diagnosis and under-treatment of childhood asthma in metropolitan France. Multidiscip Resp Med. 2012;7(1):24: www.mrmjournal.com/content/7/1/24 (access: 2013.01.25).

20. Andersen R, Newman JF. Societal and individual determinants of medical care utilization in the United States. Milbank Mem Fund Q Health Soc. 1973;51(1):95-124.

21. Partridge M. In what way may race, ethnicity or culture influence asthma outcomes? Thorax. 2000; 55(3): 175-176.

22. Siersted HC, Boldsen J, Hansen HS, Mostgaard G, Hyldebrandt N. Population-based study of risk factors for underdiagnosis of asthma in adolescence: Odense schoolchild study. BMJ. 1998; 316(7132): 651-655.

23. Baumann A, Young L, Peat JK, Hunt J, Larkin P. Asthma underrecognition and undertreatment in an Australian community. Aust N Z J Med. 1992; 22(1): 36-40.

24. van Schayck CP, van der Heijden FMMA, van den Boom G. Tirimanna PR, van Herwaarden CL. Underdiagnosis of asthma: is the doctor or the patient to blame? The DIMCA project. Thorax. 2000; 55(7): 562-565.

25. Ng Man Kwong G, Das C, Proctor AR, Whyte MKB, Primhak RA. Diagnostic and treatment behaviour in children with chronic respiratory symptoms: relationship with socioeconomic factors. Thorax. 2002; 57(8): 701-704. 